\title{
Tumor stroma ratio as a parameter for prognosis and clinicopathological behavior of oral squamous cell carcinoma: A retrospective cohort study
}

\author{
Mohammed E. Grawish ${ }^{1}$, Mona Denewar ${ }^{1}$, Rehab A. Ahmed ${ }^{* 2}$, Amr Abouzid ${ }^{3}$, Doaa AM Esmaeil ${ }^{4}$, Mohamed I. \\ Mourad $^{4}$ \\ ${ }^{1}$ Department of Oral Biology, Faculty of Dentistry, Mansoura University, Mansoura, Egypt \\ ${ }^{2}$ Department of Pathology, Faculty of Medicine, Mansoura University, Mansoura, Egypt \\ ${ }^{3}$ Department of Surgical Oncology, Oncology Center, Faculty of Medicine, Mansoura University, Mansoura, Egypt \\ ${ }^{4}$ Department of Oral Pathology, Faculty of Dentistry, Mansoura University, Mansoura, Egypt
}

Received: March 21, 2021

DOI: $10.5430 /$ jst.v10n2p36
Accepted: April 12, 2021

Online Published: April 20, 2021

\begin{abstract}
Background and aim: Tumor-stroma ratio (TSR) is the proportion of tumor cells to surrounding stroma. TSR was reported in many carcinomas as an independent strong, prognostic parameter, and could be applied routinely in diagnostic pathology. This study aimed to clarify the association between prognosis and TSR of oral squamous cell carcinoma (OSCC) and to evaluate its correlations with the clinical stages and histological grades of the studied cases.

Materials and Methods: One hundred thirty-nine anti-vimentin stained slides were digitized and analyzed for TSR scoring. TSR was classified as stroma rich $(<50 \%)$ and stroma poor $(\geq 50 \%)$. Correlations between clinicopathological variables and TSR were assessed.

Results: Microscopical examination of the studied cases revealed that 67 (48.2\%) were stroma-rich and $72(51.8 \%)$ were stroma-poor. Overall findings explained that stroma rich group had larger size, higher clinical stage, higher recurrence rate with a low disease free survival (DFS) and worse overall survival (OS) than the stroma poor.

Conclusion: The clinical outcomes of stroma rich OSCC is poor as it is associated with decreased OS and DFS of patients. Hence, TSR may be used as a prognostic independent factor for OSCC and thus, TSR can be considered as an important, low cost and valuable parameter that could be used in addition to the TNM status. Moreover, TSR might be helpful for the judgment of prognosis and for the determination of OSCC high-risk patients to treat them individually.
\end{abstract}

Key Words: TSR, SCC, Vimentin, OSCC prognosis

\section{INTRODUCTION}

Oral squamous cell carcinoma (OSCC) is the most frequent oral malignancy. Its incidence is high in developed countries and it is the 8thmost common cancer worldwide. The reliability and validity of recent diagnostic tools and techniques for early detection are still indistinct. Therefore, incisional biopsies remain the gold standard along with tactile and visual examinations. ${ }^{[1]}$ Cancer as a tissue should be viewed as an aggregate of a heterogeneous microenvironment and transformed cells. ${ }^{[2]}$ The tumor microenvironment (TME)

\footnotetext{
*Correspondence: Rehab A. Ahmed; Email: rehaballah1975@gmail.com; Address: Pathology department, Faculty of medicine, Mansoura University, Mansoura, Egypt.
} 
comprises a variety of non-neoplastic cells as endothelial cells, fibroblasts and immune cells embedded in the extracellular matrix proteins. TME interacts with cancer cells, and influences disease progression as well as the metastatic capacity of the tumor. ${ }^{[3]}$ The tumor-stroma ratio (TSR) represents the stromal component proportion around cancer cells. ${ }^{[4,5]}$ TSR was reported in many carcinomas as an independent strong, prognostic parameter, and might be incorporated in routine diagnostic pathology. ${ }^{[6]}$ It is considered as an independent prognostic marker in gastric cancer patients, ${ }^{[5]}$ colon and breast carcinomas. ${ }^{[6,7]}$ The quantity of stroma surrounding neoplastic cells can be easily estimated on hematoxylin and eosin stained tissue sections. Its assessment is potentially applicable clinically. ${ }^{[4]}$ The objective of the present study was to evaluate TSR of studied cases and to clarify the association between prognosis of OSCC with TSR. Also, this study was performed to assess the correlations of TSR with clinical stages, histological grades of the studied series.

\section{MATERIAL AND METHODS}

\subsection{Design and data collection}

The present study was a cohort retrospective and it was carried out upon 139 cases which previously diagnosed as OSCC. These cases were collected between years 1998-2018 from the oral pathology department and oncology center archives which belongs to Mansoura University, Mansoura, Egypt. Clinical and demographic data for each case were retrieved from its record sheet, including age, sex, site, clinical stage (TNM stage) and follow-up data including recurrence or free disease survival (FDS) and 3-year overall survival (OS). All patients had been treated by local wide excision. In addition, bilateral nodal dissection to cases which belong to clinical stages III and IV with nodal involvement. Histological grades were classified into well, moderately, and poorly differentiated according to Broder's system.

\subsection{Immunohistochemical staining with vimentin}

Immunostaining was done by the Vectastain $\mathrm{ABC}$ peroxidase kit (Burlingame, CA, USA). Tissue sections of $4 \mu \mathrm{m}$ thickness were sliced, dewaxed and rehydrated in deccending ethanol concentrations. Endogenous peroxidase blocking was carried out with $1 \% \mathrm{H}_{2} \mathrm{O}_{2}$ solution in methanol for 20 min. Antigen retrieval was done with citrate buffer of $\mathrm{pH} 6.0$ for $40 \mathrm{~min}$ in a $95{ }^{\circ} \mathrm{C}$ water bath then, serum blocking was occurred using $10 \%$ normal rabbit serum for $30 \mathrm{~min}$ at room temperature. Overnight incubation with primary antibodies to vimentin (Novocastra, Newcastle, UK) at $4{ }^{\circ} \mathrm{C}$ was performed. The dilution of anti-vimentin (monoclonal antibody) was 1: 50. Secondary antibody (Burlingame, CA, USA) was used at a dilution of 1: 100 for $30 \mathrm{~min}$ at room temperature. Then, washing with phosphate-buffered saline (PBS) was per-

Published by Sciedu Press formed. The chromogenic substrate 3, 3'-diaminobenzidine was utilized to visualize the reaction product. Counterstain with hematoxylin, dehydration, and mounting were done. For negative control, the primary antibody was omitted and replaced with non-immunised mouse IgG (Vector Labs).

\subsection{Computer-assisted imaging}

Using Olympus ${ }^{\circledR}$ digital camera fitted on Olympus ${ }^{\circledR}$ microscope with $1 / 2 \mathrm{X}$ photo adaptor, slides were photographed at $10 \mathrm{X}$ objective. The captured images were digitally analyzed on Intel ${ }^{\circledR}$ Core $I 5^{\circledR}$ based computer VideoTest Morphology ${ }^{\circledR}$ software (Russia) with a specific built-in routine for area and \% area measurement was utilized. Lymphocytes expressed vimentin was considered as internal positive control. Automatic detection of the area with the same configuration on the photo was performed by the computer and converts the data to a $\%$ of the total area in each field.

\subsection{Tumor-stroma ratio (TSR)}

From each slide, multiple anti-vimentin stained fields were viewed with a light microscope to select the representative area with deepest invasion for further analysis. TSR was analyzed under low magnification $(\times 4)$ to select a field with a high amount of stroma which is considered to be decisive for prognosis. ${ }^{[8,9]}$ Single vision field $(\times 10)$ with tumor cells present at all four corners of the microscopic field was used for analysis. Smooth muscle, mucin, abundant inflammatory cell infiltration, large blood vessels, hyalinization and necrosis were excluded, and the remaining area, consisting of tumor cells and stroma was used (see Figure 1). The analyzed field minus the tissue that has to be ignored is set at $100 \%$. The percentage of stroma was determined from only the neoplastic and non-ignored stromal compartments. TSR was assessed and scored by $10 \%$ intervals. $50 \%$ ratio was defined as cut off point, and patients were divided into stroma-poor (proportion of stroma $<50 \%$ and TSR was $>$ $50 \%$ i.e. high TSR) and stroma-rich (proportion of stroma $\geq$ $50 \%$ and TSR was $<50 \%$ i.e. low TSR) groups. ${ }^{[8,9]}$

\subsection{Statistical analysis}

IBM SPSS software statistics version 21.0 (IBM Corp., Armonk, NY, USA) was used for the statistical evaluation of the data obtained. For the continuous data, the Levene's test and Shapiro-Wilk test were used to test the homogeneity of variance and the normality of distribution, respectively. For comparisons between two groups, the significance of the differences between TSR less than 50\% and TSR more than $50 \%$ for each variable was determined using Mann-Whitney U non parametric statistical test. Pearson Chi-Square test was used to correlate TSR less than $50 \%$ and TSR more than $50 \%$ with their associated variables. Differences were deemed statistically significant at $P<0.05$. 


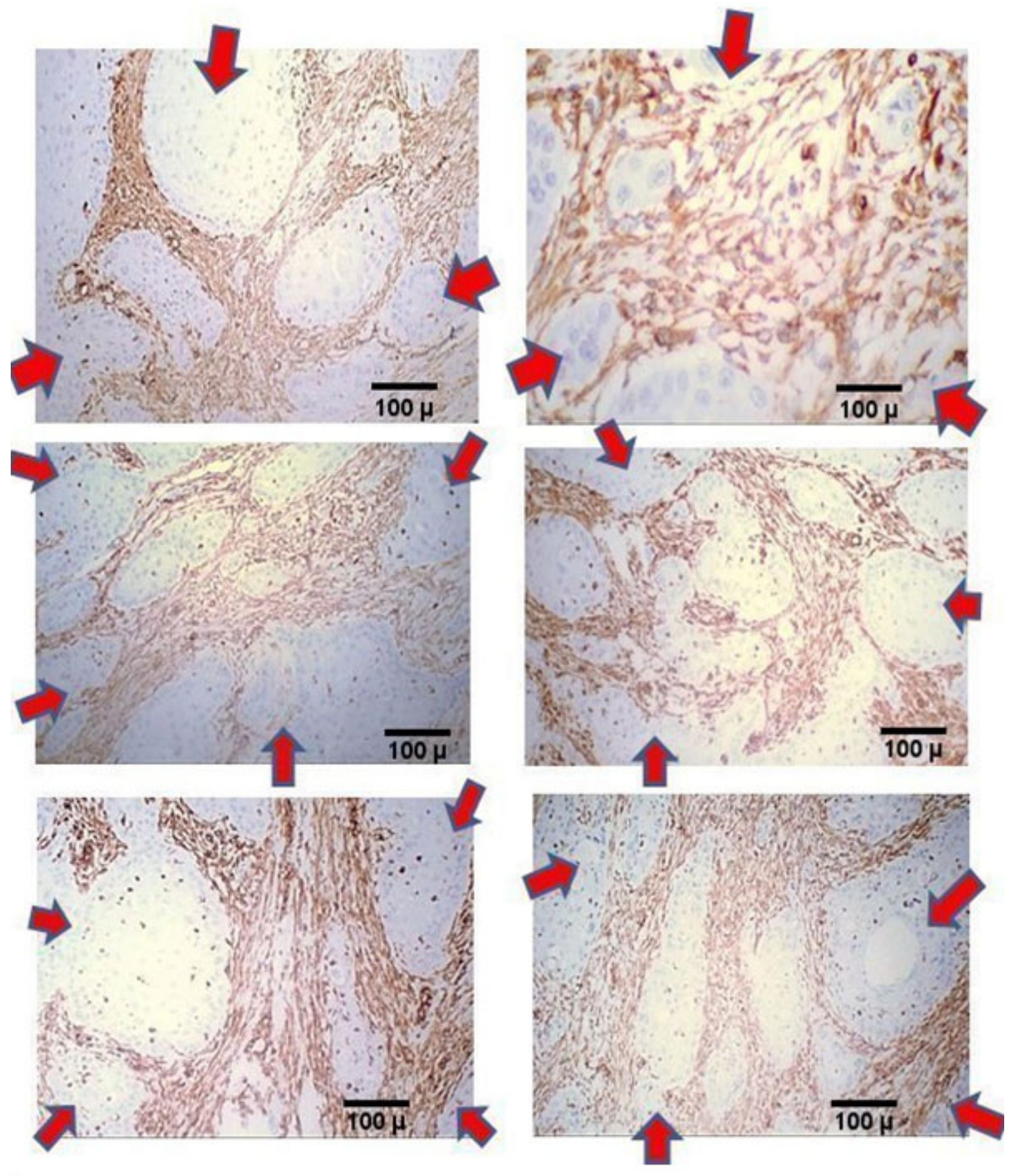

Figure 1. OSCC shown in different fields from different slides with vital tumor cells at the four corners of the microscopic field (arrows) which is suitabke for TSR assessment and scoring. Smooth muscle, mucin, aundant inflammatory cell infiltration, large blood vessels, hyalinization and necrosis were avoided (vimentin immune staining $\times 100$ magnification)

\section{RESUlTS}

\subsection{Clinicopathological and prognostic characteristics}

The present series of OSCC cases occurred between the second and eighth decades of life with mean age of 61.5 years. The gender distribution exhibited a male predominance with male to female ratio of about 2:1. The majority of studied series belonged to moderately differentiated (43.8\%) microscopically, while stages III and IV were the predominant clinically (60.4\%). These clinicopathological characteristics are summarized in Table1. Microscopical examination of the 
studied series revealed that 67 cases $(48.2 \%)$ were stromarich and 72 cases $(51.8 \%)$ were stroma-poor. The mean age for stroma rich group is lower than that of the stroma poor group (about 54 and 69 years respectively). Recurrences were common among cases with a high proportion of stroma $(37.3 \%)$, while a lower rate of recurrences was recorded at stroma poor cases $(12.5 \%)$ i.e. DFS was worse among stroma rich group than stroma poor group. Considering OS, the mean OS of stroma poor group (about 44 month) is higher than that of the stroma rich group (about 28.5 month). Also, there were more cancer related deaths among stroma rich group. Collectively, stroma rich group had larger size, higher clinical stage, higher recurrence rate and worse OS than the stroma poor (see Table 1).

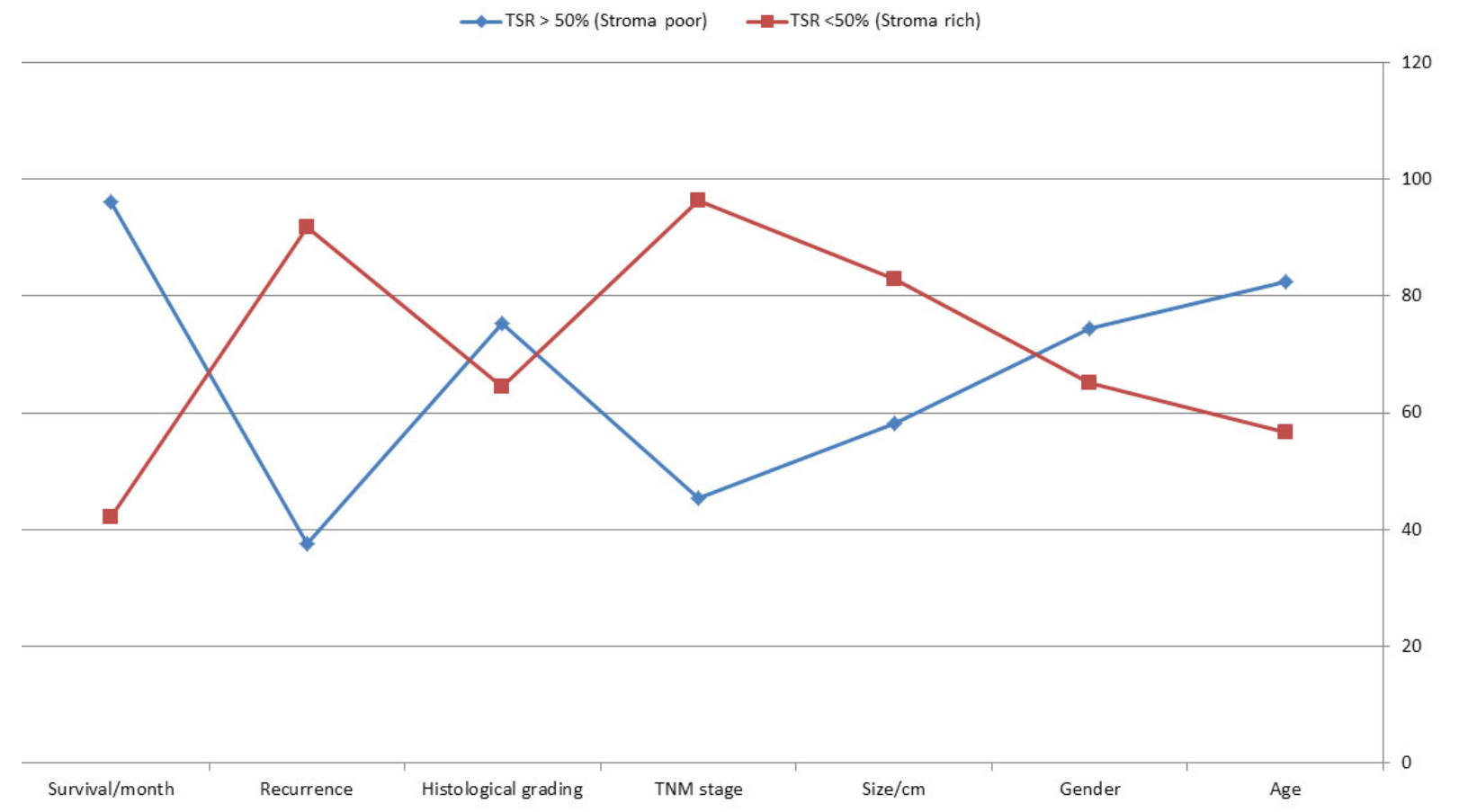

Figure 2. Line plot for the mean ranks for the different variables at TSR $>50 \%$ and TSR $<50 \%$

Table 1. The relationship between TSR and clinicopathological characteristics of the studied cases

\begin{tabular}{|c|c|c|c|c|c|c|c|c|c|c|c|c|c|c|}
\hline \multirow{3}{*}{ variables } & \multirow{2}{*}{\multicolumn{2}{|c|}{$\begin{array}{l}\text { Age } \\
\text { range }\end{array}$}} & \multirow{3}{*}{$\begin{array}{l}\text { Mean } \\
\pm \text { SD }\end{array}$} & \multicolumn{2}{|c|}{ Gender } & \multirow{3}{*}{$\begin{array}{l}\text { Size } \\
\\
\text { Mean } \\
\pm \text { SD }\end{array}$} & \multicolumn{2}{|c|}{ TNM stage } & \multicolumn{3}{|c|}{ Histological grade } & \multicolumn{2}{|c|}{ Recurrence } & \multirow{3}{*}{$\begin{array}{l}\begin{array}{l}\text { Survival } \\
\text { (month) }\end{array} \\
\\
\text { Mean } \\
\pm \text { SD }\end{array}$} \\
\hline & & & & Male & Female & & $\begin{array}{l}\text { I } \\
\& \\
\text { II }\end{array}$ & $\begin{array}{l}\text { III } \\
\& \\
\text { IV }\end{array}$ & well & Moderately & poorly & present & absent & \\
\hline & Min. & Max. & & $\begin{array}{l}\text { No. } \\
(\%)\end{array}$ & $\begin{array}{l}\text { No. } \\
(\%)\end{array}$ & & $\begin{array}{l}\text { No. } \\
(\%)\end{array}$ & $\begin{array}{l}\text { No. } \\
(\%)\end{array}$ & $\begin{array}{l}\text { No. } \\
(\%)\end{array}$ & $\begin{array}{l}\text { No. } \\
(\%)\end{array}$ & $\begin{array}{l}\text { No. } \\
(\%)\end{array}$ & $\begin{array}{l}\text { No. } \\
(\%)\end{array}$ & $\begin{array}{l}\text { No. } \\
\text { (\%) }\end{array}$ & \\
\hline $\begin{array}{l}\text { TSR }> \\
\mathbf{5 0 \%} \\
\text { (Stroma } \\
\text { poor) }\end{array}$ & 38 & 78 & $68.96 \pm 15.34$ & $\begin{array}{l}47 \\
(65.3)\end{array}$ & $\begin{array}{l}25 \\
(34.7)\end{array}$ & $1.156 \pm 0.268$ & $\begin{array}{l}48 \\
(66.7)\end{array}$ & $\begin{array}{l}24 \\
(33.3)\end{array}$ & $\begin{array}{l}25 \\
(34.7)\end{array}$ & $\begin{array}{l}31 \\
(43.1)\end{array}$ & $\begin{array}{l}16 \\
(22.2)\end{array}$ & $\begin{array}{l}9 \\
(12.5)\end{array}$ & $\begin{array}{l}63 \\
(87.5)\end{array}$ & $44.195 \pm 5.85$ \\
\hline $\begin{array}{l}\text { TSR }<50 \% \\
\text { (Stroma } \\
\text { rich) }\end{array}$ & 16 & 63 & $54.04 \pm 8.7$ & $\begin{array}{l}45 \\
(67.2)\end{array}$ & $\begin{array}{l}22 \\
(32.8)\end{array}$ & $2.89 \pm 0.435$ & $\begin{array}{l}7 \\
(10.5)\end{array}$ & $\begin{array}{l}60 \\
(89.5)\end{array}$ & $\begin{array}{l}19 \\
(28.4)\end{array}$ & $\begin{array}{l}30 \\
(44.8)\end{array}$ & $\begin{array}{l}18 \\
(26.8)\end{array}$ & $\begin{array}{l}25 \\
(37.3)\end{array}$ & $\begin{array}{l}42 \\
(62.7)\end{array}$ & $28.473 \pm 2.32$ \\
\hline Total & 16 & 78 & $61.5 \pm 12.1$ & $\begin{array}{l}92 \\
(66.2)\end{array}$ & $\begin{array}{l}47 \\
(33.8)\end{array}$ & $2.563 \pm 0.526$ & $\begin{array}{l}55 \\
(39.6)\end{array}$ & $\begin{array}{l}84 \\
(60.4)\end{array}$ & $\begin{array}{l}44 \\
(31.7)\end{array}$ & $\begin{array}{l}61 \\
(43.8)\end{array}$ & $\begin{array}{l}34 \\
(24.5)\end{array}$ & $\begin{array}{l}56 \\
(40.3)\end{array}$ & $\begin{array}{l}83 \\
(59.7)\end{array}$ & $36.834 \pm 4.1$ \\
\hline
\end{tabular}

\subsection{Other Statistical findings}

The mean ranks for the different variables at TSR $>50 \%$ and TSR $<50 \%$ are summarized in Table 2 and Figure 2. Mann Whitney $U$ test revealed significant difference between stroma rich group and stroma poor group in relation to age,

Published by Sciedu Press

size, TNM staging, recurrence rate and OS. Meanwhile, a non-significant difference was found between the two examined groups in relation to histological grade and gender (see Table 2).

Pearson Chi-square test for correlation showed significant 
inverse association between percentage of stromal compo- size, TNM stage, recurrence rate or DFS and OS on the other nent and age of OSCC cases as the younger was the age, side. In contrast, a non-significant correlation was observed the higher was the stroma. While, a significant positive cor- between TSR and histological grade of the studied cases (see relation was detected between TSR on one side and tumor Table 3).

Table 2. Mean ranks for the different variables at TSR $>50 \%$ and TSR $<50 \%$ and their statistical significance with Mann-Whitney U

\begin{tabular}{|c|c|c|c|c|c|}
\hline \multirow{2}{*}{ Variable } & \multicolumn{2}{|l|}{ Mean Rank } & \multicolumn{3}{|c|}{ Mann-Whitney U } \\
\hline & TSR $>50 \%$ (Stroma poor) & TSR $<50 \%$ (Stroma rich) & U value & $\mathbf{Z}$ & P value \\
\hline Age & 82.41 & 56.66 & 1518.500 & -3.769 & .000 \\
\hline Gender & 74.53 & 65.13 & 2086.000 & -1.696 & .090 \\
\hline $\mathrm{Size} / \mathrm{cm}$ & 58.11 & 82.78 & 1556.000 & -3.661 & .000 \\
\hline TNM stage & 45.49 & 96.34 & 647.500 & -7.744 & .000 \\
\hline $\begin{array}{l}\text { Histological } \\
\text { grading }\end{array}$ & 75.21 & 64.40 & 2037.000 & -1.696 & .090 \\
\hline Recurrence & 37.67 & 91.66 & 357.500 & -8.886 & .000 \\
\hline Survival/month & 96.00 & 42.06 & 540.000 & -7.901 & .000 \\
\hline
\end{tabular}

Table 3. Pearson Chi-Square test for correlating TSR $>50 \%$ and TSR $<50 \%$ with their associated variables

\begin{tabular}{|c|c|c|c|c|c|c|}
\hline \multirow{2}{*}{ Variable } & \multicolumn{3}{|c|}{ TSR $>50 \%$ (Stroma poor) } & \multicolumn{3}{|c|}{ TSR $<50 \%$ (Stroma rich) } \\
\hline & $X^{2}$ & df & P value & $X^{2}$ & df & P value \\
\hline Age & 580.491 & 252 & .000 & 588.510 & 320 & .000 \\
\hline Gender & 33.048 & 36 & .425 & 30.776 & 32 & .389 \\
\hline Size/cm & 243.564 & 156 & .000 & 190.836 & 100 & .000 \\
\hline TNM stage & 177.162 & 36 & .000 & 72.277 & 30 & .000 \\
\hline $\begin{array}{l}\text { Histological } \\
\text { grading }\end{array}$ & 66.833 & 68.379 & .591 & 60.534 & 63.341 & .425 \\
\hline Recurrence & 163.152 & 60 & .000 & 19.699 & 15.699 & .000 \\
\hline Survival/month & 460.366 & 441 & .000 & 144.090 & 126 & .000 \\
\hline
\end{tabular}

\section{Discussion}

Stromal element has an importantand essential role in metastasis and invasion of tumors. TSR is attracting ascending considerations at tumor prognosis predicting fields. Nevertheless, prognostic value of TSR in solid tumors requires extra illumination. ${ }^{[4]}$ It had been defined as a prognostic independent parameter in colon and rectal carcinomas, ${ }^{[10]}$ but now it is extended to several cancer types. ${ }^{[11]}$

Here, for the first time, the prognostic value of TSR in a great series of OSCC has been investigated. The age range of the studied OSCC series was wide and extended between the 2nd and the 8th decades with a mean age of 61.5 years. This finding is consistent with Ragin et al. ${ }^{[12]}$ who reported 60 years as a median age of patients with HNSCC. In addition, Pireset al. ${ }^{[13]}$ found that 62.3 years was the mean age of their SCC patients. According to Llewellyn et al. ${ }^{[14]}$ and Torossian et al. ${ }^{[15]} \mathrm{SCC}$ is uncommon among patients with young age. Few SCC cases (1\% to $6 \%$ ) could occur under the age of 40 years demonstrating that OSCC incidence was very rare in children and adolescent. In agreement with Pires et al. ${ }^{[13]}$ and Zedan et al., ${ }^{[16]}$ the incidence rate among the cases of the current study was more common in males than in females.

Considering clinical staging (TNM staging) of SCC, majority of the studied cases was presented with advanced clinical stages (III and IV). This is almost the same as described by Zedan et al. ${ }^{[16]}$ and Haqet al. ${ }^{[17]}$ This shows late detection or diagnosis in our country, hence, most of cases were in advanced stages. Meanwhile, Manuel et al. ${ }^{[18]}$ and Okada et al. ${ }^{[19]}$ disagree with these findings as their cases were demonstrated at early clinical stages. This could be attributed to unawareness about the disease, poor referral system and high ignorance rate in our country. Moreover, Shah et al. ${ }^{[20]}$ indicated late oral cancer diagnosis in Pakistan (stages III \& IV) and require immediate professional and public attentions.

Surprisingly and in contrast to several previous reports, moderately differentiated SCC was the most common histopathological grade at the time of presentation in our ward. This 
finding disagrees with Zedan et al. ${ }^{[16]}$ and Miyagi et al. ${ }^{[21]}$ whom recorded that well differentiated form, was the most prevalent type of SCC. Moreover, Haq et al. ${ }^{[17]}$ showed that the most prevalent SCC variant histologically was the poorly differentiated. Also, Yanofsky et al. ${ }^{[22]}$ found that poorly differentiated SCC variant was much less frequent than well differentiated ${ }^{[22]}$ ). These conflicting results may be explained in part by heterogeneity between study populations, due to concomitant genetic alterations, selection biases, and in differences in diagnostic techniques. ${ }^{\text {[23] }}$

Our findings suggested that, stroma rich group had larger size, higher clinical stage, higher recurrence rate and worse OS than the stroma poor. This is consistent with Wu et al.(2016) who stated that total hazard ratio showed that stroma rich tumors was associated with poor DFS and OS of their patients. ${ }^{[4]}$ Similarly, Wang et al. ${ }^{[24]}$ presented the same finding in esophageal squamous cell carcinoma. In addition, Mesker et al. [10]reported significant worse overall and disease-free survivals in patients with low TSR $(<50 \%) .^{[10]}$ Moreover, Zhang et al. ${ }^{[25]}$ who analyzed many prognostic factors in relation to TSR and found significant association between age, tumor diameter, differentiation grade and pTNM clinical stage with five years OS, DFS and TSR in multivariate analysis.

These findings could be attributed to Zhu et al.;26] Madar et al.;27] Pietras and Ostman; ${ }^{[28]}$ Kawashiri et al.; ${ }^{[29]}$ Massagué; [30] Kim et al.; ${ }^{[31]}$ Li et al.; ${ }^{[32]}$ Schottelius and Dinter; ${ }^{[33]}$ Kalluri and Zeisberg; ${ }^{[34]}$ De Wever and Mareel ${ }^{[35]}$ who reported that cancer-associated fibroblasts (CAFs) and myofibroblasts can induce transition of carcinoma epithelial cells to mesenchymal and yield various cytokines and growth factors, proteolytic enzymes like matrix metalloproteinases and angiogenic molecules. These molecules enable growth and promotion of tumor, as well as local invasion of surrounding tissue and enhancing spread of distant metastasis. Furthermore, myofibroblasts could inhibit immune cells in- filtration into tumor which may contributethe cancer cells to escape from the immune surveillance. Hence, increased stromal components proportion may produce poor clinical outcomes of tumor as a result of promotion of an aggressive potential.

Also, Nguyen et al. ${ }^{[36]}$ indicated that the tumor-related stroma components including many different cell types, various secreted cytokines and factors and the ECM could assist stromal cells communication with cancer cells, thus, cancer cells have the ability to colonize the microenvironment and to form metastatic deposits. At the same line, Cirri and Chiarugi; ${ }^{[37]}$ Bremnes et al. ${ }^{[38]}$ explained that the activation of CAFs could promote progression and tumor growth by many variable tumor-secreted factors, like $\alpha$-smooth muscle actin, fibroblast activation protein, platelet-derived growth factor, interleukin 6 and basic fibroblast growth factor.

\section{CONCLUSION}

In conclusion, stroma rich OSCC is associated with poor clinical outcomes as it is associated with decreased OS and DFS of patients. Hence, TSR may serve as a prognostic independent factor for OSCC. Thus, TSR can be considered as an important, low cost and valuable parameter that could be used in addition to the TNM status. Moreover, TSR might be helpful for the judgment of prognosis and for the determination of OSCC high-risk patients to treat them individually.

\section{RECOMMENDATION}

Plans are necessary to investigate mechanisms of stroma formation using model systems and molecular techniques. Focusing at the components of TME should have great potential in the clinical practice as they play a great role in tumor progression, promotion and metastatic potential of tumors.

\section{CONFLicts of InTEREST Disclosure}

No potential conflicts of interest are disclosed.

\section{REFERENCES}

[1] Del CG, Villa A, Tarsitano A, et al. Current trends in oral cancer: a review. Can Cell Microenviron. 2016; 3: e1332.

[2] Arcangeli A, Crociani O, Bencini L. Interaction of tumour cells with their microenvironment: ion channels and cell adhesion molecules. A focus on pancreatic cancer.Philos Trans R SocLond B Biol Sci. 2014; 369(1638): 20130101. PMid:24493749. https://doi.org/10.1 098/rstb. 2013.0101

[3] van Pelt GW, Sandberg TP, Morreau H, et al.The tumour-stroma ratio in colon cancer: the biological role and its prognostic impact. Histopathology. 2018; 73(2): 197-206. PMid:29457843. https: //doi.org/10.1111/his.13489

[4] Wu J, Liang C, Chen M, et al. Association between tumor-stroma ratio and prognosis in solid tumor patients: a systematic re- view and meta-analysis. Oncotarget. 2016; 7(42): 68954-68965. PMid:27661111. https://doi.org/10.18632/oncotarget.12 135

[5] Aurello P, Berardi G, Giulitti D, et al.Tumor-Stroma Ratio is an independent predictor for overall survival and disease free survival in gastric cancer patients.Surgeon. 2017; 15(6): 329-335. PMid:28629870. https://doi.org/10.1016/j.surge.2017.05.007

[6] van Pelt GW, Kjær-Frifeldt S, van Krieken JHJM, et al. Scoring the tumor-stroma ratio in colon cancer: procedure and recommendations.Virchows Arch. 2018; 473(4): 405-412. PMid:30030621. https://doi.org/10.1007/s00428-018-2408-z

[7] Vangangelt KMH, van Pelt GW, Engels CC, et al.Prognostic value of tumor-stroma ratio combined with the immune status of tumors in invasive breast carcinoma. Breast Cancer Res Treat. 2018; 168(3): 
601-612. PMid:29273955. https://doi.org/10.1007/s10549 $-017-4617-6$

[8] Lee D, Ham IH, Son SY, et al. Intratumor stromal proportion predicts aggressive phenotype of gastric signet ring cell carcinomas. Gastric Cancer. 2017; 20(4): 591-601. PMid:27858181. https: //doi.org/10.1007/s10120-016-0669-2

[9] Zhou ZH, Ji CD, Zhu J, et al. The prognostic value and pathobiological significance of Glasgow microenvironment score in gastric cancer. J Cancer Res ClinOncol. 2017; 143(5): 883-894. PMid:28180998. https://doi.org/10.1007/s00432-017-2346-1

[10] Mesker WE, Junggeburt JM, Szuhai K, et al.The carcinoma-stromal ratio of colon carcinoma is an independent factor for survival compared to lymph node status and tumor stage. Cell Oncol. 2007; 29(5): 387-398. PMid:17726261. https ://doi.org/10.1155/2007/1 75276

[11] Liu J, Li J, Chen Y, et al. Tumor-stroma ratio is an independent predictor for survival in early cervical carcinoma. GynecolOncol. 2014; 132(1): 81-86. PMid:24219981. https://doi.org/10.1016/j. ygyno.2013.11.003

[12] Ragin CC, Modugno F, Gollin SM. The epidemiology and risk factors of head and neck cancer: a focus on human papillomavirus. J Dent Res. 2007; 86(2): 104-114. PMid:17251508. https://doi. org/10.1177/154405910708600202

[13] Pires FR, Ramos AB, Oliveira JB, et al. Oral squamous cell carcinoma: clinicopathological features from 346 cases from a single oral pathology service during an 8-year period. J Appl Oral Sci. 2013; 21(5): 460-467. PMid:24212993. https ://doi .org/10.1590/16 79-775720130317

[14] Llewellyn CD, Johnson NW, Warnakulasuriya KA. Risk factors for squamous cell carcinoma of the oral cavity in young peoplea comprehensive literature review. Oral Oncol. 2001; 37(5): 401-418. https ://doi.org/10.1016/S1368-8375(00)00135-4

[15] Torossian JM, Beziat JL, Philip T, et al. Squamous cell carcinoma of the tongue in a 13-year-old boy.J Oral Maxillofac Surg. 2000; 58(12): 1407-1410. PMid:11117690. https://doi.org/10.105 3/joms. 2000.18276

[16] Zedan W, Mourad MI2, El-Aziz SM3, et al. Cytogenetic significance of chromosome 17 aberrations and P53 gene mutations as prognostic markers in oral squamous cell carcinoma.DiagnPathol. 2015; 10: 2. PMid:25881131. https://doi .org/10.1186/s13000-015-0 232-1

[17] Haq MEU, Abid H, Hanif MK, et al. Frequency and Pattern of Oral and Maxillo-facial Carcinomas. J Orofacial Res Ann. 2009; 15(4): 171-175.

[18] Manuel S, Raghavan SK, Pandey M, et al. Survival in patients under 45 years with squamous cell carcinoma of the oral tongue. Int J Oral Maxillofac Surg. 2003; 32(2): 167-173. PMid:12729777. https://doi.org/10.1054/ijom.2002.0271

[19] Okada Y, Mataga I, Katagiri M, et al. An analysis of cervical lymph nodes metastasis in oral squamous cell carcinoma. Relationship between grade of histopathological malignancy and lymph nodes metastasis. Int J Oral Maxillofac Surg. 2003; 32(3): 284-288. PMid:12767876. https://doi.org/10.1054/ijom.2002.0303

[20] Shah I, Sefvan O, Luqman U, et al. Clinical stage of oral cancer patients at the time of initial diagnosis. J Ayub Med Coll Abbottabad. 2010; 22(3): 61-63.

[21] Miyagi J, Tsuhako K, Kinjo T, et al. Recent striking changes in histological differentiation and rate of human papillomavirus infection in squamous cell carcinoma of the lung in Okinawa, a subtropical island in southern Japan. J ClinPathol. 2000; 53(9): 676-684. PMid:11041057. https://doi.org/10.1136/jcp.53.9.676

[22] Yanofsky VR, Mercer SE, Phelps RG. Histopathological variants of cutaneous squamous cell carcinoma: a review.J Skin Cancer. 2011;
2011: 210813. PMid:21234325. https://doi.org/10.1155/20 $11 / 210813$

[23] Ueda C, Uchiyama T, Ohno H. Immunoglobulin (Ig)/BCL6 versus non-Ig/BCL6 gene fusion in diffuse large B-cell lymphoma corresponds to a high- versus low-level expression of BCL6 mRNA.Blood. 2002; 99(7): 2624-2625. PMid:11926184. https://doi.org/10 .1182/blood-2001-11-0117

[24] Wang K, Ma W, Wang J, et al.Tumor-stroma ratio is an independent predictor for survival in esophageal squamous cell carcinoma. J ThoracOncol. 2012; 7(9): 1457-1461. PMid:22843085. https ://doi.org/10.1097/JT0.0b013e318260dfe8

[25] Zhang T, Xu J, Shen H, et al.Tumor-stroma ratio is an independent predictor for survival in NSCLC.Int J ClinExpPathol. 2015; 8(9): 1348-55. eCollection 2015.

[26] Zhu QC, Gao RY, Wu W, et al. Epithelial-mesenchymal transition and its role in the pathogenesis of colorectal cancer. Asian Pac J Cancer Prev. 2013; 14(5): 2689-98. PMid:23803016. https : //doi.org/10.7314/APJCP.2013.14.5.2689

[27] Madar S, Goldstein I, Rotter V. Cancer associated fibroblasts'more than meets the eye. Trends Mol Med. 2013; 19(8): 447-453. PMid:23769623. https://doi.org/10.1016/j.molmed. 2013. 05.0049

[28] Pietras K, Ostman A. Hallmarks of cancer: interactions with the tumor stroma. Exp Cell Res. 2010; 316(8): 1324-1331. PMid:20211171. https://doi.org/10.1016/j.yexcr. 2010.0 2.045

[29] Kawashiri S, Tanaka A, Noguchi N, et al. Significance of stromal desmoplasia and myofibroblast appearance at the invasive front in squamous cell carcinoma of the oral cavity. Head Neck. 2009; 31(10): 1346-1353. PMid:19373786. https ://doi .org/10.100 2/hed. 21097

[30] Massagué J. TGFbeta in Cancer. Cell. 2008; 134(2): 215-230. PMid:18662538. https ://doi.org/10.1016/j.cell.2008.07 .001

[31] Kim R, Emi M, Tanabe K. Cancer immunoediting from immune surveillance to immune escape. Immunology. 2007; 121(1): 1-14. PMid:17386080. https ://doi.org/10.1111/j.1365-2567.20 $07.02587 . \mathrm{x}$

[32] Li H, Fan X, Houghton J. Tumor microenvironment: the role of the tumor stroma in cancer. J Cell Biochem. 2007; 101(4): 805-815. PMid:17226777. https ://doi.org/10.1002/jcb. 21159

[33] Schottelius AJ, Dinter H. Cytokines, NF-kappaB, microenvironment, intestinal inflammation and cancer. Cancer Treat Res. 2006; 130: 6787. PMid:16610703. https://doi.org/10.1007/0-387-26283 $-0 \_3$

[34] Kalluri R, Zeisberg M. Fibroblasts in cancer. Nat Rev Cancer. 2006; 6(5): 392-401. PMid:16572188. https://doi.org/10.1038/nr c1877

[35] De Wever O, Mareel M. Role of tissue stroma in cancer cell invasion. J Pathol. 2003; 200(4): 429-447. PMid:12845611. https : //doi.org/10.1002/path.1398

[36] Nguyen DX, Bos PD, Massagué J. Metastasis: from dissemination to organ-specific colonization. Nat Rev Cancer. 2009; 9(4): 274-284. PMid:19308067. https://doi.org/10.1038/nrc2622

[37] Haq MEU, Abid H, Hanif MK, et al. Frequency and Pattern of Oral and Maxillo-facial Carcinomas. J Orofacial Res Ann. 2009; 15(4): 171-175.

[38] Bremnes RM, Dønnem T, Al-Saad S, et al. The role of tumor stroma in cancer progression and prognosis: emphasis on carcinomaassociated fibroblasts and non-small cell lung cancer. J ThoracOncol. 2011; 6(1): 209-217. PMid:21107292. https ://doi .org/10.109 7/JT0.0b013e3181f8a1bd 